\title{
Effects of bioturbation and plant roots on salt marsh biogeochemistry: a mesocosm study
}

\author{
Britta Gribsholt*, Erik Kristensen**
}

Institute of Biology, Odense University-Sydddansk Universitet, Campusvej 55, 5230 Odense M, Denmark

\begin{abstract}
The impact of benthic macrofauna (Nereis diversicolor) and macrophytes (Spartina anglica) on the dynamics of microbial mineralization rates and pathways in saltmarsh sediment was studied over 1 growing season. Measurements were conducted in 4 saltmarsh mesocosms subjected to a natural tidal regime, and inhabited by either flora, fauna or both, or kept without the presence of macroorganisms. Total benthic mineralization was measured during spring, summer and fall as sediment oxygen uptake and carbon dioxide release under air-exposed as well as inundated conditions, while anaerobic mineralization was quantified as sulfate reduction. Porewater concentration profiles of total carbon dioxide $\left(\mathrm{TCO}_{2}\right)$, dissolved organic carbon (DOC), $\mathrm{SO}_{4}{ }^{2-}, \mathrm{Cl}^{-}$and $\mathrm{Fe}^{2+}$ were determined monthly. The presence of fauna had minor effects on plant growth, while sediment vegetated by $S$. anglica renders the habitat unsuitable for $N$. diversicolor, possibly due to food limitation. Without the presence of macroorganisms, a dense algal mat (Vaucheria sp.) developed on the sediment surface. As a result, the sediment was greatly reduced with benthic respiration completely dominated by sulfate reduction. Grazing by fauna ( $N$. diversicolor) kept the sediment surface free of epibenthic microalgae, and irrigation oxidized the top 15 to $20 \mathrm{~cm}$ of the sediment by enhancing porewater exchange with overlying water. Porewater $\mathrm{TCO}_{2}, \mathrm{DOC}$ and $\mathrm{Fe}^{2+}$ only accumulated below 15 to $20 \mathrm{~cm}$ depth. Sulfate reduction was still the dominating degradation pathway, accounting for 50 to $60 \%$ of the total microbial mineralization. The presence of flora ( $S$. anglica) enhanced total microbial mineralization but lowered the importance of sulfate reduction (22 to $54 \%$ ). Porewater constituents such as DOC and $\mathrm{TCO}_{2}$ were kept low and relatively evenly distributed with depth. The oxidizing capacity of $S$. anglica was evident throughout the sediment column. The presence of both flora and fauna produced the largest increase in oxic as well as total microbial mineralization rates. In conclusion, the mesocosm approach simulated natural salt marsh conditions well, and the results provide good evidence for the interactions between flora and fauna as well as their impact on sediment geochemistry.
\end{abstract}

KEY WORDS: Salt marsh mesocosm - Benthic mineralization · Bioturbation · Spartina $\cdot$ Sulfate reduction $\cdot \mathrm{CO}_{2}$ release $\cdot \mathrm{O}_{2}$ uptake $\cdot$ Roots

\section{INTRODUCTION}

Salt marshes are coastal areas characterized by dense vegetation of herbs, grasses or low shrubs and subject to periodical inundation of saline water (Adam 1990). An improved understanding of biogeochemical

\footnotetext{
*Present address: Center for Estuarine and Coastal Ecology, Netherlands Institute of Ecology, PO Box 140, 4400 AC Yerseke, The Netherlands

${ }^{* *}$ Corresponding author. E-mail: ebk@biology.sdu.dk
}

processes in salt marshes is crucial when the role of these habitats for estuarine ecosystem dynamics is evaluated. Salt marsh sediments are rich in organic matter primarily due to the high plant production, and supplemented by sedimentation of organic matter from external sources or from microphytobenthic production (Boorman 1999). The sediment is usually anoxic a few $\mathrm{mm}$ below the surface (Alongi 1998) and sulfate reduction is often considered the dominant microbial carbon mineralization pathway (Hines et al. 1989, Alongi 1998). However, various more or less complex 
interactions between plants, animals and microorganisms (Adam 1990) are important in controlling biogeochemical processes in the sediment.

The perennial marsh grass Spartina anglica is the most widespread species in the pioneering zone of salt marshes in NW Europe. Like other marsh grasses, it translocates oxygen to its extensive root and rhizome system. The associated leakage of $\mathrm{O}_{2}$ from root surfaces creates oxidized subsurface microniches (rhizospheres) (Sundby et al. 1998, Holmer et al. 2002). Furthermore, leakage of dissolved organic carbon (DOC) from Spartina roots to the rhizosphere enhances microbial activity in the sediment (Hines et al. 1989, 1999). By virtue of their feeding and burrowing activities, benthic macrofauna also affects sediment chemistry. Biogenic reworking, and particularly irrigation associated with solute diffusion across burrow walls, may result in extensive exchange of sediment porewater with overlying water (Aller 2001). The polychaete Nereis diversicolor is an abundant intertidal macroinvertebrate in many $S$. anglica saltmarshes and adjacent mudflats (Jackson 1985, Mason et al. 1991). While the bioturbation effects of $N$. diversicolor has not been elucidated in saltmarsh sediment, the presence of this worm is known to more than double the release of $\mathrm{TCO}_{2}$ in intertidal sediments (Kristensen \& Hansen 1999). Furthermore, benthic macrofauna may affect the growth and survival of marsh grasses. Thus, the mud fiddler crab Uca pugnax enhances the standing stock of S. alterniflora (Montague 1982, Bertness 1985), while $N$. diversicolor limits the colonization and establishment of $S$. anglica (Emmerson 2000).

The purpose of this study was to evaluate the dynamics of microbial mineralization and sediment biogeochemistry in salt marsh sediment over a growing season, when subjected to the presence of plants and/or animals. This was done through a combination of porewater, solid phase and rate measurements in
4 salt marsh mesocosms inhabited by either flora (Spartina anglica), fauna (Nereis diversicolor) or both, or without any macroorganisms. Total benthic mineralization was measured during spring, summer and fall as sediment oxygen uptake and carbon dioxide release under air-exposed as well as inundated conditions, while anaerobic mineralization was quantified as sulfate reduction. Concentration profiles of porewater $\mathrm{TCO}_{2}, \mathrm{DOC}, \mathrm{SO}_{4}{ }^{2-}, \mathrm{Cl}^{-}$and $\mathrm{Fe}^{2+}$ were determined on a monthly basis from spring to fall. The results clearly show effects of plants and animals and their interaction as well as the temporal and spatial dynamics of the system.

\section{MATERIALS AND METHODS}

Experimental setup. Four mesocosms, Meso I to IV (125 cm high, $150 \mathrm{~cm}$ in diameter), were established in June 1998, at the pier near the Research Center for Aquatic Biology (Odense University-SDU) in Kerteminde, Denmark (Fig. 1a). Approximately $1 \mathrm{~m}^{3}$ of salt marsh sediment was added to each of the half buried mesocosms, resulting in a sediment depth of $\sim 70 \mathrm{~cm}$, with the sediment surface elevated $10 \mathrm{~cm}$ above the surrounding ground level. The salt marsh sediment, which was collected in the Danish Wadden Sea near the island of Rømø, had been stored on land for $3 \mathrm{wk}$ prior to transfer to the mesocosms. After $1 \mathrm{wk}$, the sediment was homogenized and compacted by stamping within the mesocosm. The mesocosm were subsequently left water-covered for $2 \mathrm{wk}$, before the experimental inundation regime was applied.

The sediment was flooded once every $12.25 \mathrm{~h}$ by pumping seawater from Kerteminde Fjord, via a reservoir and through nylon mesh-covered drainpipes. One set of drainpipes, established at the sediment surface along half of the mesocosm circumference (Fig. 1b), allowed water to seep slowly onto the sediment without turbulence and resuspension of the sediment surface. The mesocosms were drained by passive outflow through another set of nylon mesh-covered drainpipes just below the sediment surface along the remaining mesocosm circumference (Fig. 1b). The total period of inundation was approximately $1.5 \mathrm{~h}$ during every tidal cycle. Maximum water cover was $15 \mathrm{~cm}$ above the sediment surface. The sediment was pre-conditioned with tidal cover for 8 mo before introduction of plants and animals.

Young shoots of Spartina anglica were collected from the salt marsh at
Fig. 1. Mesocosm design. (A) Side view; (B) above view. One mesocosm consists of a $2000 \mathrm{l}$ polyethylene tank with a solid bottom dug $60 \mathrm{~cm}$ into the ground. Nylon-covered drainpipes allow in- and outflow of tidal water at the sediment surface, just above the surrounding ground level 
Ho Bight, Denmark (Gribsholt \& Kristensen 2002), in late March 1999. The 5 to $10 \mathrm{~cm}$ tall shoots were separated into individual plants, rinsed in seawater and planted equally spaced at $10 \mathrm{~cm}$ distance $\left(100 \mathrm{~m}^{-2}\right)$ in Meso III and IV. A density of 1000 ind. $\mathrm{m}^{-2}$ of the polychaete Nereis diversicolor (natural size distribution) were added to Meso II and III in May 1999. The worms were collected from Fællesstrand, Denmark (Kristensen 1993). No plants or fauna were added to Meso I, which served as a control (Table 1). The mesocosms were then left undisturbed and exposed to the prevailing air temperatures $\left(-10\right.$ to $\left.+25^{\circ} \mathrm{C}\right)$, precipitation (650 $\mathrm{mm} \mathrm{yr}^{-1}$ ) and light conditions of the area, along with water from Kerteminde Fjord varying in salinity from 10 to $25 \mathrm{ppt}$ and temperatures from 0 to $20^{\circ} \mathrm{C}$, for 1 growing season before sampling was initiated in March 2000.

Oxygen and carbon dioxide exchange. Total benthic metabolism was determined as dark fluxes of oxygen $\left(\mathrm{O}_{2}\right)$ and dissolved inorganic carbon $\left(\mathrm{CO}_{2}\right)$ across the sediment-water interface and measured both during inundation and air exposure. Three $15 \mathrm{~cm}$ long sediment cores $(8.0 \mathrm{~cm}$ in diameter) were collected from each mesocosm and brought to the laboratory in March, June and September 2000. Cores from Meso III and IV were collected between individual Spartina anglica plants. Epibenthic algae and benthic infauna, on the other hand, were not excluded from cores collected from any of the mesocosms. Inundated flux determinations were done by $4 \mathrm{~h}$ closed-core incubations with a 6 to $8 \mathrm{~cm}$ water column continuously stirred by small $(1 \mathrm{~cm})$ rotating magnet bars $(50 \mathrm{rmp})$. Start and end samples for oxygen were analyzed by the standard Winkler technique (Parson et al. 1984) and those for $\mathrm{TCO}_{2}$ were analyzed within $24 \mathrm{~h}$ by the flow injection/diffusion cell technique (Hall \& Aller 1992). Oxygen concentration change was assumed constant with time during incubations because oxygen never decreased below $100 \mu \mathrm{M}$.

After careful removal of the overlying water, cores were adjusted upwards allowing only 1 to $2 \mathrm{~cm}$ air space (50 to $100 \mathrm{ml}$ ), and air-exposed flux measurements were conducted on the same cores. Oxygen consumption was calculated using the concentration change determined with a polarographic oxygen electrode (Radiometer) in the headspace for a 5 to $10 \mathrm{~h}$ incubation period (Kristensen et al. 1992). After termination of oxygen uptake measurements the airexposed cores were moved to a flow-through system for determination of carbon dioxide release. The cores were sealed with 2 port lids, which were connected to a peristaltic pump via polyethylene tubing. Moistened atmospheric air was pulled into the headspace of the core tube at a rate of 10 to $12 \mathrm{ml} \mathrm{min}^{-1}$, and the gas exiting the core tubes passed through a LI-COR
Table 1. Experimental design. (+) indicates addition of plants or animals to the mesososm in spring 1999; (0) indicates the absence of plants or animals

\begin{tabular}{|lllll|}
\hline Mesocosm & I & II & III & IV \\
\hline Spartina anglica & 0 & 0 & + & + \\
Nereis diversicolor & 0 & + & + & 0 \\
\hline
\end{tabular}

infrared gas analyzer (Model LI-6251). When steady state was reached after 30 to $60 \mathrm{~min}$, the $\left[\mathrm{CO}_{2}\right]$ in the excurrent gas was recorded. $\mathrm{CO}_{2}$ production was calculated as the concentration difference between the excurrent gas and atmospheric air, and related to the rate of gas flow through the headspace. All incubations were done at near in situ temperatures of $10^{\circ} \mathrm{C}$ in March and $15^{\circ} \mathrm{C}$ in June and September.

Sulfate reduction and solid-phase sampling and analysis. Sediment was sampled by collecting $55 \mathrm{~cm}$ long intact sediment cores by pushing Plexiglas tubes $(8.0 \mathrm{~cm}$ in diameter) into the sediment. Tubes were sealed with rubber stoppers and pulled from the sediment. Four replicate cores were collected from each mesocosm in March, June and September 2000. Cores were extruded stepwise and cut at 4, 9, 19, 34 and $49 \mathrm{~cm}$ depth, and in order to avoid oxidation of the sediment, immediately subsampled for sulfate reduction rate (SRR) and particulate Fe(II) measurements.

Subsamples for determination of SRR were obtained by pushing a cut-off $20 \mathrm{ml}$ syringe $2 \mathrm{~cm}$ vertically into the sediment. After retrieval, the syringes were closed immediately with rubber stoppers and stored in darkness. SRRs were determined by a modification of the core-injection technique (Jørgensen 1978). Within $1 \mathrm{~h}$ of subsampling, $3 \mu$ radiolabeled sulfate $\left({ }^{35} \mathrm{~S}_{-} \mathrm{SO}_{4}{ }^{2-}\right.$, $70 \mathrm{kBq}$ ) were injected into each cut-off syringe. Subsamples were incubated in the dark for $2 \mathrm{~h}$ at $15^{\circ} \mathrm{C}$. Rates for the March incubations were subsequently corrected to in situ temperatures using a $Q_{10}$ of 3 (Jørgensen 1977). The incubations were terminated and sulfides preserved by transferring the sediment directly into $50 \mathrm{ml}$ screw-capped plastic centrifuge tubes containing $10 \mathrm{ml}$ of $20 \%$ (w/w) zinc acetate solution. Subsequently, the tubes were vigorously shaken and stored frozen until further handling. The sediment was distilled according to the 2-step procedures of Fossing \& Jørgensen (1989) as described in Gribsholt (2001). The total pools of acid volatile sulfide (TRS $\left.\mathrm{TVS}_{\mathrm{AVS}}\right)$ and chromium reducible sulfur $\left(\mathrm{TRS}_{\mathrm{CRS}}\right)$ in distillation traps were determined by the spectrophotometric method of Cline (1969).

For particulate iron analysis, $300 \mathrm{mg}$ of sediment was transferred to $4 \mathrm{ml}$ of $0.5 \mathrm{M} \mathrm{HCl}$ in pre-weighed plastic vials and stored frozen for later analysis. Before analy- 
sis, the vials were shaken for $1 \mathrm{~h}$ at room temperature, centrifuged at $3000 \mathrm{rpm}$ for $5 \mathrm{~min}$, and [Fe(II)] in the supernatant was determined spectrophotometrically (550 nm) after chelation with Ferrozine $(0.02 \%$ in 50 mM HEPES, pH 7; Stookey 1970).

Separate subsamples from all depth intervals were collected in tightly sealed plastic bags and kept at $5^{\circ} \mathrm{C}$ for determination of sediment characteristics within $3 \mathrm{~d}$. Sediment density was obtained from the wet weight of a known sediment volume. Porosity was calculated from water loss after drying at $105^{\circ} \mathrm{C}$ for $6 \mathrm{~h}$. Organic content was determined as loss-on-ignition (LOI) at $520^{\circ} \mathrm{C}$ for $6 \mathrm{~h}$ and as particulate organic carbon (POC) and nitrogen (PON) determined with a Carlo Erba Elemental Analyser EA 1100A after the method of Kristensen \& Andersen (1987). The sediment remaining after subsampling was returned to the mesocosms to avoid collapse of the sediment surrounding sampling spots.

Porewater sampling and analysis. Porewater was sampled every 4 wk from March to October 2000 using standard Eijkelkamp Rhizon Soil Moisture Samplers ${ }^{\circledR}$ (Eijkelkamp Agrisearch Equipment), consisting of $5 \mathrm{~cm}$ porous polymer tubing with a mean pore size of $0.1 \mu \mathrm{m}$. The soil moisture samplers were dug into the sediment and positioned horizontally at 5, 10, 20, 35 and $50 \mathrm{~cm}$ depth in March 2000. Four replicate series of samplers were positioned in each mesocosm. Each sampler was connected to the surface by a $70 \mathrm{~cm}$ long (1.0 $\mathrm{mm}$ in diameter) extension tube. Porewater was collected by applying vacuum by $60 \mathrm{ml}$ syringes. As the total dead volume of the tubing was $\sim 0.5 \mathrm{ml}$, the first $\sim 1 \mathrm{ml}$ porewater was discarded. After this, 6 to 10 $\mathrm{ml}$ porewater was retrieved from each sampler. Prior to positioning, all soil moisture samplers, tubes, connectors and syringes were rinsed several times in MilliQ water, to avoid contamination of the porewater. One soil moisture sampler was positioned vertically into the sediment surface in each mesocosm and left throughout the entire sampling period. New samplers, positioned parallel to the old sampler during each sampling occasion, revealed that up to 8 mo of continuous burial of the soil moisture samplers in the sediment had no impact on the measured porewater constituents, as there were no significant differences (ANOVA, $\mathrm{p}<0.05$ ) in neither $\mathrm{Fe}^{2+}$, DOC nor $\mathrm{TCO}_{2}$ concentrations in porewater obtained from new and old samplers over time in any of the mesocosms (data not shown).

Porewater for the analysis of $\mathrm{TCO}_{2}$ and DOC was stored in $4 \mathrm{ml}$ glass vials capped with Teflon-coated butyl rubber septa leaving no gas phase. $\mathrm{TCO}_{2}$ was analyzed immediately as described earlier (see 'Oxygen and carbon dioxide exchange' above). The remaining sample was frozen for later DOC determination by high temperature catalytic combustion (HTCC) on a Shimadzu TCO-5000 Total Organic Carbon Analyzer after acidification with $2 \mathrm{M} \mathrm{HCl}(\mathrm{pH}<3)$ to remove dissolved inorganic carbon. Porewater samples of $1 \mathrm{ml}$ were acidified with $10 \mu \mathrm{l}$ of $6 \mathrm{M} \mathrm{HCl}$ and stored frozen for later determination of dissolved $\mathrm{Fe}^{2+}, \mathrm{SO}_{4}{ }^{2-}$ and $\mathrm{Cl}^{-}$concentrations. $\mathrm{SO}_{4}{ }^{2-}$ and $\mathrm{Cl}^{-}$were measured by ion chromatography with a Dionex auto-suppressed anion system (IonPac AS4A-SC column and ASRS suppressor). Dissolved iron concentrations were determined on acidified samples by spectrophotometry (550 nm) after chelation with $0.02 \%$ ferrozine (50 mM HEPES, pH 7) according to Stookey (1970).

Flora and fauna. The aboveground plant biomass in Mesos III and IV were determined in August 2000 by harvesting all material in 3 randomly selected $20 \times$ $20 \mathrm{~cm}$ plots. The plant material was divided into leaves, stems and dead material. The leaf area of each fraction was measured with a portable leaf area meter (Model LI-3000, Lambda Instruments). Dry weight was determined by drying at $60^{\circ} \mathrm{C}$ for $48 \mathrm{~h}$.

At the termination of the experimental sampling series in October 2000, 4 cores $(55 \mathrm{~cm}$ long, $8.0 \mathrm{~cm}$ in diameter) were collected from all mesocosms and sieved (1 mm mesh size) for the determination of Nereis diversicolor density and size distribution as well as root biomass. All polychaetes were preserved in $4 \%$ formalin before individual dry weight was determined by drying at $60^{\circ} \mathrm{C}$ for $24 \mathrm{~h}$. Root and rhizome biomass were determined in $0-5,5-10,10-20,20-35$ and $35-50 \mathrm{~cm}$ depth intervals by drying at $60^{\circ} \mathrm{C}$ for $24 \mathrm{~h}$. No distinction was made between live and dead root material.

\section{RESULTS}

\section{Visual observations}

The sediment surface of the 4 mesocosms appeared very different throughout the sampling time from March to October 2000. In Meso I, a dark green, velvet-looking mat of the yellow-green algae Vaucheria sp. appeared in spring and developed to $10 \mathrm{~cm}$ thickness by midsummer with no further changes for the remaining experimental period. Distinct layers of purple and white sulfide oxidizing bacteria developed within and below the mat. In Meso II, the sediment surface was riddled with Nereis diversicolor burrows. The sediment surface always appeared soft, brownish/gray and was devoid of visible epibenthic algae. $N$. diversicolor were often observed feeding at the sediment surface. The plants in Mesos III and IV had established themselves well over the previous growing season where they increased in density and flowered. At the onset of the experiment (March 2000), the old decaying stems were removed. The new shoots thrived and grew to approximately $1 \mathrm{~m}$ height in midsummer and 
flowered in August. Some N. diversicolor burrows were evident at the sediment surface of Meso III between the plants, and the sediment was relatively soft compared to Meso IV. The sediment surfaces of Meso III and IV had similar brownish coloration and were devoid of visible epibenthic algae.

\section{Sediment characteristics}

There was no significant difference in the sediment density $(1.38 \pm 0.05)$, water content $(49.9 \pm 3.2 \%)$ or porosity $(0.69 \pm 0.04)$ throughout the sampling period or between the mesocosms. The organic matter content, measured as LOI, POC and PON, was relatively constant with depth, and there was no significant difference in the depth-integrated pools between mesocosms (Table 2). However, a significant decrease in LOI (12 to $22 \%$ ) as well as POC and PON ( 7 to $9 \%$ ) occurred from March to September $(t$-test, $\mathrm{p}<0.05)$. The molar C:N ratio, on the other hand, did not change with depth and time, and always ranged between 13 and 14 .

\section{Flora and fauna}

The total Spartina anglica biomass did not differ significantly between the 2 vegetated mesocosms (III and IV) in August (Table 3). However, the leaf area appeared slightly lower and the root biomass slightly larger in the non-bioturbated Meso IV than in the bioturbated Meso III. The difference in root biomass was primarily due to a higher root density in the top $5 \mathrm{~cm}$ of the Meso IV sediment. The sediment contained remains of roots and rhizomes brought along during sediment collection prior to mesocosm establishment, as evident by the unexpected belowground biomass in Mesos I and II. This indigenous dead biomass was equivalent to 34 to $49 \%$ of the total root and rhizome biomass in Mesos III and IV.
Table 2. Initial and final sediment characteristics in the 4 mesocosms. Particulate organic carbon (POC) and nitrogen (PON) are given as 0 to $50 \mathrm{~cm}$ depth-integrated values. Values are shown as mean $\pm \mathrm{SD}(\mathrm{n}=3)$. LOI: loss-on-ignition

\begin{tabular}{|lcccc|}
\hline Mesocosm & $\begin{array}{c}\text { LOI } \\
(\%)\end{array}$ & $\begin{array}{c}\text { POC } \\
\left(\mathrm{mmol} \mathrm{cm}^{-2}\right)\end{array}$ & $\begin{array}{c}\text { PON } \\
\left(\mathrm{mmol} \mathrm{cm}^{-2}\right)\end{array}$ & C:N \\
\hline March & & & & \\
I & $11.2 \pm 0.4$ & $231.1 \pm 4.1$ & $16.8 \pm 0.2$ & $13.7 \pm 0.1$ \\
II & $11.3 \pm 0.3$ & $232.5 \pm 6.4$ & $16.9 \pm 0.4$ & $13.8 \pm 0.0$ \\
III & $10.2 \pm 0.3$ & $227.0 \pm 3.2$ & $16.5 \pm 0.4$ & $13.8 \pm 0.5$ \\
IV & $10.4 \pm 0.5$ & $227.0 \pm 0.7$ & $17.4 \pm 0.3$ & $13.1 \pm 0.2$ \\
September & & & & \\
I & $8.9 \pm 0.3$ & $215.4 \pm 5.3$ & $15.6 \pm 0.7$ & $13.8 \pm 0.3$ \\
II & $8.8 \pm 0.3$ & $214.3 \pm 3.1$ & $15.5 \pm 0.6$ & $13.9 \pm 0.6$ \\
III & $8.6 \pm 0.4$ & $211.3 \pm 9.9$ & $15.1 \pm 1.0$ & $14.0 \pm 0.6$ \\
IV & $9.2 \pm 0.3$ & $209.3 \pm 6.7$ & $17.1 \pm 1.5$ & $13.0 \pm 0.4$ \\
\multicolumn{7}{l}{} & & & & \\
\hline
\end{tabular}

Nereis diversicolor was successfully excluded from Mesos I and IV (Table 3), and no other marine macrofauna were present in any of the mesocosms. The density of $N$. diversicolor in the unvegetated Meso II was around 4000 ind. $\mathrm{m}^{-2}$ in October 2000, which was 10 times higher than in the vegetated Meso III. The worms were evenly distributed in Meso II, while the large variance in Meso III indicates a clumped distribution. The size distribution of $N$. diversicolor differed markedly between the 2 mesocosms. In Meso II, the population structure reflected a natural pattern of a reproducing population with numerous small and relatively few large individuals, while the few individuals obtained from Meso III were relatively large. $N$. diversicolor were primarily found in the top $5 \mathrm{~cm}$, but a few individuals appeared as far down as $20 \mathrm{~cm}$ depth.

\section{Oxygen and carbon dioxide exchange}

The oxygen uptake generally increased over time (1.1 to 3.1 times). The increase was most dramatic in

Table 3. Quantification of Spartina anglica and Nereis diversicolor in the 4 mesocosms. Aboveground biomass (live and dead) and specific leaf area of $S$. anglica were determined in August 2000. Root and rhizome biomass (0 to $50 \mathrm{~cm}$ depth) and the density and total biomass of $N$. diversicolor were determined in October 2000. dw $=$ dry weight. Values are given as mean \pm SD (n $=3$ to 4 )

\begin{tabular}{|lccrr|}
\hline Mesocosm & I & II & III & IV \\
\hline Spartina anglica & & & & \\
Total biomass $\left(\mathrm{kg} \mathrm{dw} \mathrm{m}^{-2}\right)$ & 0 & 0 & $1.6 \pm 0.2$ & $1.7 \pm 0.4$ \\
Leaf area $\left(\mathrm{m}^{-2} \mathrm{~kg}^{-1} \mathrm{dw} \mathrm{leaf}\right)$ & 0 & $1.7 \pm 0.1$ & $14.6 \pm 0.4$ & $4.5 \pm 0.7$ \\
Root biomass $\left(\mathrm{kg} \mathrm{dw} \mathrm{m}^{-2}\right)$ & $1.5 \pm 0.2$ & & & $4.4 \pm 0.5$ \\
Nereis diversicolor & & $3850 \pm 640$ & $400 \pm 490$ & 0 \\
Density $\left(\mathrm{m}^{-2}\right)$ & 0 & $26.8 \pm 6.2$ & $6.7 \pm 8.2$ & 0 \\
Biomass $\left(\mathrm{g} \mathrm{dw} \mathrm{m}^{-2}\right)$ & 0 & $7.0 \pm 11.4$ & $18.7 \pm 16.6$ & 0 \\
Mean individual biomass $(\mathrm{mg} \mathrm{dw})$ & 0 & & \\
\hline
\end{tabular}


Meso I during air exposure, where respiration and decay of the thick algal mat, which was not removed during incubations, contributed significantly. Sediment oxygen uptake was generally higher (1.3 to 4.9 times) during air exposure than during inundation, except for Meso II, where the opposite pattern actually was observed in June (Fig. 2). Significant differences $(t$-test) in oxygen uptake under the different inundation conditions, however, were observed only in June for all mesocosms and in September for Meso I. Oxygen uptake during inundation was significantly lower ( $t$-test, $\mathrm{p}<0.05)$ in vegetated sediment compared to unvegetated, while no such general pattern was evident during air exposure.
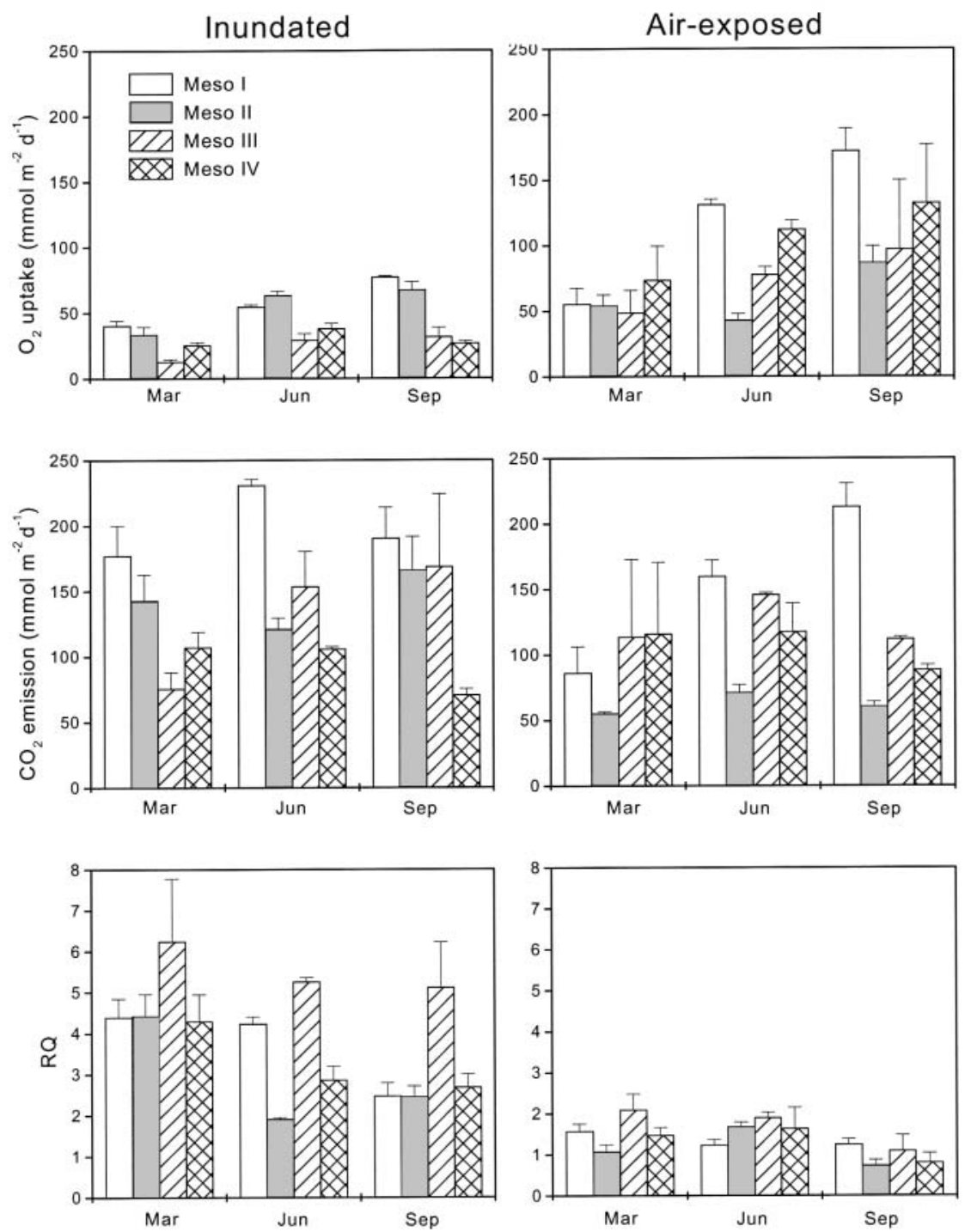

Fig. 2. $\mathrm{O}_{2}$ uptake, $\mathrm{CO}_{2}$ emission and respiratory quotient (RQ) in the 4 mesocosms during inundation and air exposure in March, June and September 2000 $($ mean $\pm \mathrm{SD}, \mathrm{n}=3$ )
Carbon dioxide release was significantly higher $(t-$ test, $\mathrm{p}<0.05$ ) under inundated than air-exposed conditions in Mesos I and II, except for Meso I in September. The highest $\mathrm{CO}_{2}$ emission under both inundation conditions was generally observed in Meso I. As with the oxygen flux, these excessive rates in Meso I must be attributed to the presence of the algal mat. Thus, in March, before the algal mat in Meso I had developed, the $\mathrm{CO}_{2}$ flux was not significantly different in Mesos I and II. The air-exposed $\mathrm{CO}_{2}$ emission was significantly lower $(t$-test, $\mathrm{p}<0.05)$ in the unvegetated Meso II than in the other mesocosms throughout the experiment, while no specific pattern occurred during inundation. Tidal cover and season did not affect the $\mathrm{CO}_{2}$ emission from the 2 vegetated mesocosms (III and IV) significantly ( $t$-test). The community respiratory quotient (RQ) calculated as the ratio between $\mathrm{CO}_{2}$ production and sediment $\mathrm{O}_{2}$ uptake was always highest (1.8 to 4.7 times) during inundation, except for Meso II in June, where no effect of water coverage was noted. RQ was 25 to $175 \%$ higher in Meso III (5 to 6) than in the other mesocosms during inundation, whereas low and relatively similar values were evident in all air-exposed mesocosms at all times $(0.7$ to 2.1$)$.

\section{Sulfate reduction rates and particulate reduced sulfur and iron pools}

Volume-specific sulfate reduction rates varied from 27 to $170 \mathrm{nmol} \mathrm{cm} \mathrm{cm}^{-3}$ $\mathrm{d}^{-1}$ throughout the top $50 \mathrm{~cm}$ of the sediment (Fig. 3A). Sulfate reduction showed erratic depth patterns in all mesocosms and there was no specific seasonal variability in the depth distribution. The variability in the sulfate reduction rates at any given time and depth was larger in the sediments vegetated by Spartina anglica than in the unvegetated mesocosms. There were no statistically significant ( $t$-test) differences in the 0 to $50 \mathrm{~cm}$ depthintegrated sulfate reduction (ISRR) between mesocosms or over the season (Fig. 4A). The depth pattern of total reduced sulfur (TRS) was also relatively similar in all mesocosms and at all times (Fig. 3B). Exceptions are Meso II, where a large pool appeared at $20 \mathrm{~cm}$ depth in September, and Meso IV, where con- 
centrations were high in the deeper parts of the sediment in March and September. The depth integrated TRS pool increased significantly over the sampling season in the unvegetated mesocosms, while no specific pattern was observed in the vegetated mesocosms (Fig. 4B). AVS accounted for an increasing fraction of TRS with time in all the mesocosms, but CRS always contributed $>70 \%$ of the total reduced sulfide (Fig. $4 \mathrm{C}$ ). The overall turnover time of reduced sulfur pools in the
0 to $50 \mathrm{~cm}$ interval was similar ( 3 to $5 \mathrm{mo}$ ) in all 4 mesocosms in March. Due to the increased TRS pools in Mesos I and II, the turnover time in these mesocosms almost doubled from March to September. In the 2 vegetated mesocosms, on the other hand, turnover time decreased from March to June and remained relatively fast (2 to $4 \mathrm{mo}$ ) in September (Fig. 4D).

The depth distribution of $\mathrm{HCl}$ extractable [Fe(II)] varied between mesocosms (Fig. 3C). [Fe(II)] decreased

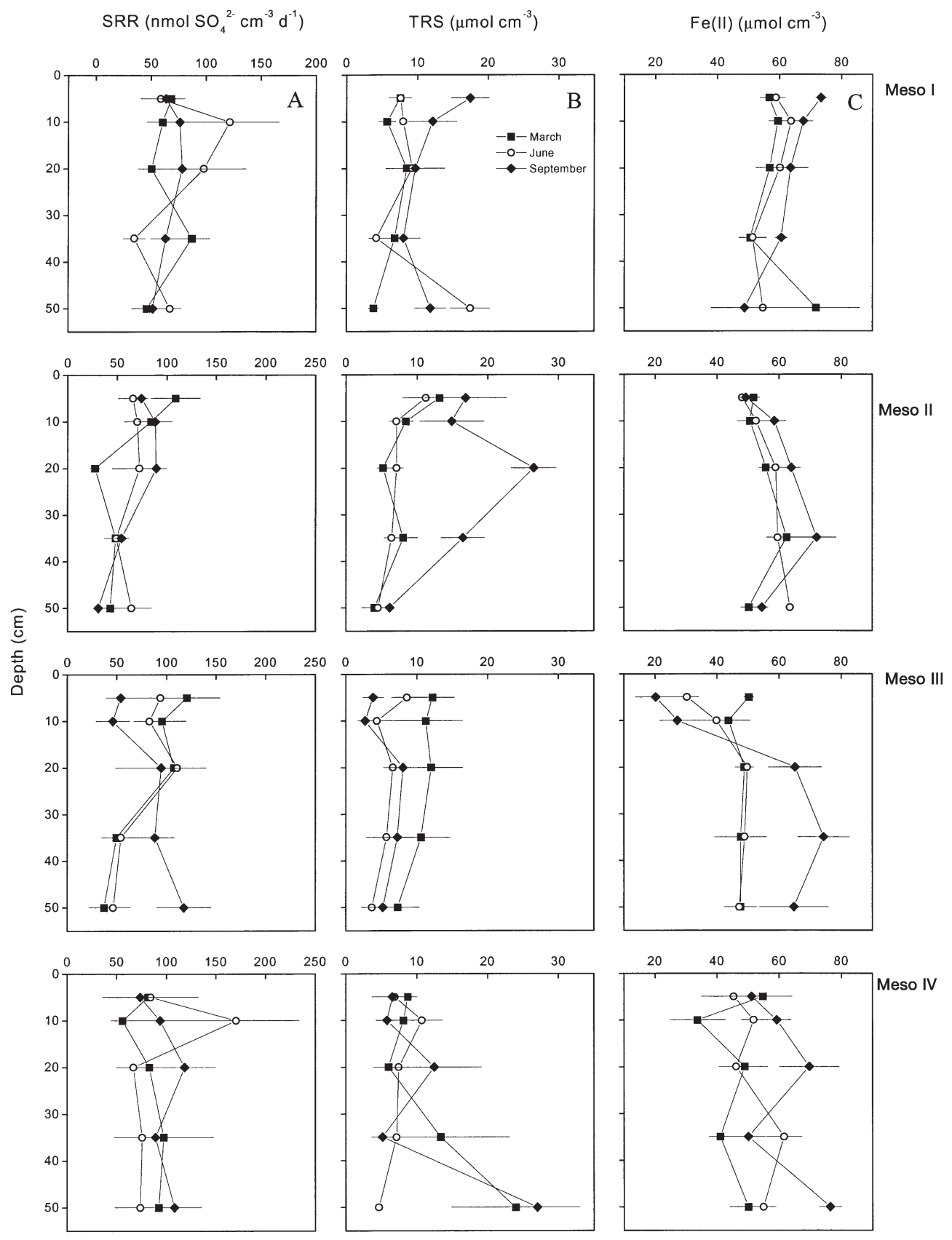

Fig. 3. Vertical distribution of (A) sulfate reduction rates (SRR), (B) total reduced inorganic sulfur pools (TRS) and (C) particulate [Fe(II)] in the 4 mesocosms in March, June and September 2000 (mean $\pm \mathrm{SD}, \mathrm{n}=4$ ) 
with depth in Meso I, whereas increasing or constant levels were observed with depth in Meso II. The concentrations were generally low in the top $10 \mathrm{~cm}$ sediment of Meso III, and, except for March, reached a constantly high level below this depth, while concentrations were relatively erratic, but constant throughout the depth investigated in Meso IV. [Fe(II)] generally increased from March to September.
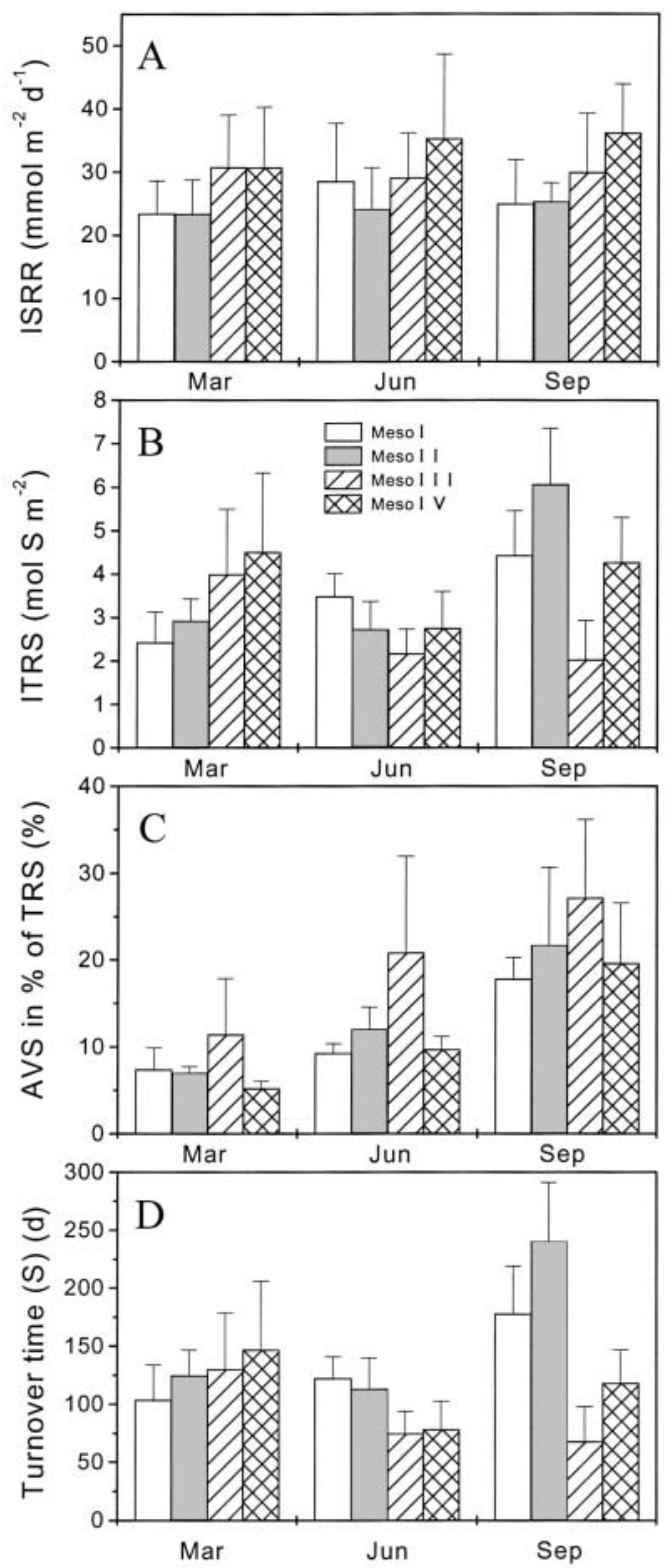

Fig. 4. (A) Depth-integrated (0 to $50 \mathrm{~cm}$ ) sulfate reduction rate (ISRR); (B) depth-integrated $(0$ to $50 \mathrm{~cm}$ ) total reducible inorganic sulfur pools (ITRS); (C) acid volatile sulfur (AVS) as percentage of the total pool of reduced inorganic sulfur; (D) turnover time of sulfide in the 4 mesocosms (mean $\pm \mathrm{SD}, \mathrm{n}=4$ ) in March, June and September 2000

\section{Porewater solutes}

Porewater $\mathrm{TCO}_{2}$ accumulated over time in all 4 mesocosms, but the actual concentrations and depth patterns varied considerably (Fig. 5). The concentrations in Meso I were relatively uniform (15 to $20 \mathrm{mM}$ ) with depth for most of the experimental period, but a subsurface maximum developed at 10 to $30 \mathrm{~cm}$ with concentrations up to $35 \mathrm{mM}$ in September and October. Meso II, on the other hand, showed a distinct $\mathrm{TCO}_{2}$ increase with sediment depth throughout the entire sampling period. While the $\mathrm{TCO}_{2}$ in the upper $10 \mathrm{~cm}$ remained at a low level $(<10 \mathrm{mM})$, a rapid accumulation was evident below $20 \mathrm{~cm}$ from mid to late summer (up to $40 \mathrm{mM}$ ). $\mathrm{TCO}_{2}$ concentrations in Meso III were uniformly low (5 to $10 \mathrm{mM}$ ) in spring, but over the summer levels increased gradually to about $15 \mathrm{mM}$, with a subsurface maximum of $20 \mathrm{mM}$ at $20 \mathrm{~cm}$ depth. A similar accumulation pattern over time was observed in Meso IV, but here the summer subsurface maximum occurred at $10 \mathrm{~cm}$ depth. The depth-integrated $\mathrm{TCO}_{2}$ pool of all 4 mesocosms increased from March to October in the sequence I > II > III > IV.

Porewater DOC showed a spatial and temporal distribution pattern similar to that of $\mathrm{CO}_{2}$, with generally highest concentrations in Meso II and lowest in the 2 vegetated mesocosms (Mesos III and IV; Fig. 6). Levels in Meso I varied between 2 and $5 \mathrm{mM}$, and DOC accumulated over time with temporary subsurface peaks around $20 \mathrm{~cm}$ depth. DOC levels in Meso II increased with depth and accumulated gradually over time with occasional subsurface peaks (up to $8 \mathrm{mM}$ ) around 30 to $40 \mathrm{~cm}$ depth. The main difference between Meso III and IV, where levels were always below $3 \mathrm{mM}$, was observed near the sediment surface. DOC levels in the upper $10 \mathrm{~cm}$ were much lower in Meso III than in Meso IV. Except for early spring, Meso IV had a subsurface minimum at 30 to $40 \mathrm{~cm}$ depth. The depth-integrated DOC pool of all 4 mesocosms increased from March to October in the sequence I > II > III > IV.

Porewater sulfate decreased over time in a more or less chaotic vertical pattern (Fig. 7). Sulfate generally increased with depth at all times in Meso I, whereas a subsurface minimum gradually developed at 20 to $40 \mathrm{~cm}$ depth in Meso II. The lowest $\left[\mathrm{SO}_{4}{ }^{2-}\right]$ recorded in both unvegetated mesocosms were $\sim 5 \mathrm{mM}$ in September/October. Changes in $\left[\mathrm{SO}_{4}{ }^{2-}\right]\left(\Delta \mathrm{SO}_{4}{ }^{2-}\right)$, normalized for changes in chlorinity according to the formula:

$$
\begin{aligned}
\Delta \mathrm{SO}_{4}{ }^{2-}= & {\left[\mathrm{SO}_{4}{ }^{2-}\right]_{\text {measured }}-\left(\left[\mathrm{Cl}^{-}\right]_{\text {measured }} \times\right.} \\
& \left(\left[\mathrm{SO}_{4}{ }^{2-}\right] /\left[\mathrm{Cl}^{-}\right]\right)_{\text {seawater }}
\end{aligned}
$$

where $\left(\left[\mathrm{SO}_{4}{ }^{2-}\right] /\left[\mathrm{Cl}^{-}\right]\right)_{\text {seawater }}=5.14 \times 10^{2}$, are shown in Fig. 8. Negative values of $\Delta \mathrm{SO}_{4}{ }^{2}$ in Mesos I and II during late summer indicate that the low $\left[\mathrm{SO}_{4}{ }^{2-}\right]$ were caused by selective removal of sulfate, e.g. by sulfate- 
reducing bacteria. $\left[\mathrm{SO}_{4}{ }^{2-}\right]$ were relatively uniform with depth in Mesos III and IV but exhibited a slight subsurface decrease during summer. However, concentrations only occasionally decreased below $12.5 \mathrm{mM}$ and $\Delta \mathrm{SO}_{4}{ }^{2}$ remained positive in these mesocosms, indicating net sulfide oxidation, except for some subsurface sulfate removal around $20 \mathrm{~cm}$ depth in Meso IV.

Dissolved $\mathrm{Fe}^{2+}$ showed contrasting distribution patterns between mesocosms (Fig. 9). The highest concentrations in Meso I was observed near the sediment surface in spring. Concentrations generally decreased with depth except for a marked subsurface minimum in May-June. $\left[\mathrm{Fe}^{2+}\right]$ increased gradually from very low concentrations near the surface to $3 \mathrm{mM}$ at $50 \mathrm{~cm}$ depth in Meso II, until a sudden drop to $<0.75 \mathrm{mM}$ occurred throughout the entire sediment column in
June. However, in July $\left[\mathrm{Fe}^{2+}\right]$ returned to the spring levels, and the depth stratification was regained. Meso III showed a $\mathrm{Fe}^{2+}$ pattern similar to Meso II, but with generally higher levels and a less dramatic decrease in the deeper parts of the sediment in June. In Meso IV, there was a subsurface maximum of $\mathrm{Fe}^{2+}$ around $10 \mathrm{~cm}$ depth in spring and late summer, whereas the strong subsurface minimum, which appeared at $30 \mathrm{~cm}$ depth in June, was evident all through summer.

\section{DISCUSSION}

Mesocosms present a unique opportunity to observe the biogeochemical behavior of salt marsh sediments affected by selected plants and animals, and exposed

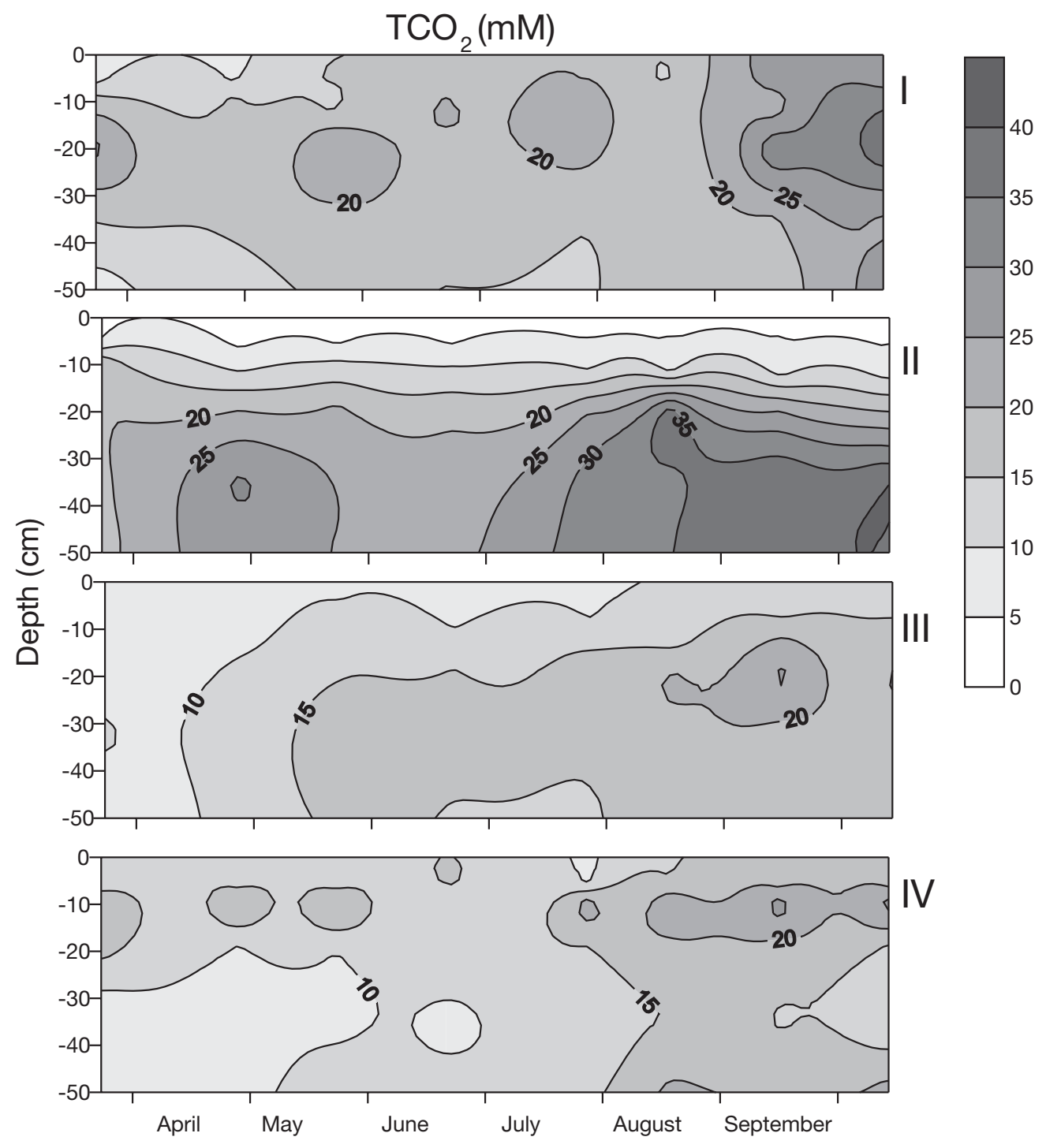

Fig. 5. Porewater $\left[\mathrm{TCO}_{2}\right]$ in the 4 mesocosms from March to October 2000 


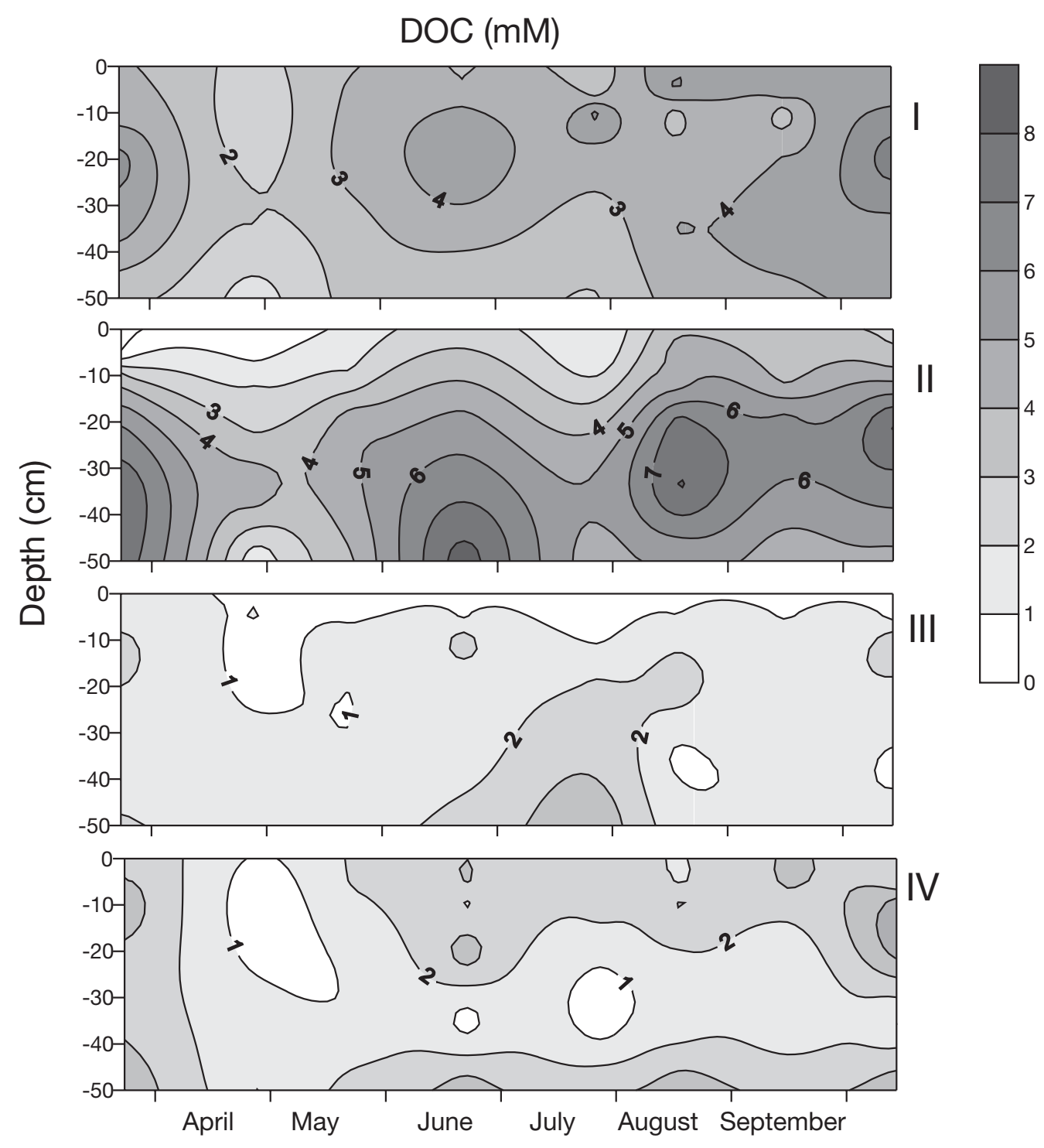

Fig. 6. Porewater [DOC] in the 4 mesocosms from March to October 2000

to a natural inundation regime. By applying in situ sippers, we non-destructively elucidated the temporal and spatial dynamics of the systems. While recognizing that $2 \mathrm{yr}$ is insufficient time to establish a 'mature' marsh system, we believe that the behavior of plants, animals and basic sediment processes in our mesocosms mimic natural conditions of a pioneer marsh well. First, the aboveground plant biomass is comparable to field observations, and although the total belowground biomass in the vegetated mesocosms were low (37 to $65 \%$ ) compared to field observations, the depth distribution of the roots and rhizomes were similar to those observed in Spartina anglica salt marshes (B. Gribsholt unpubl. data). Second, the population of Nereis diversicolor in Meso II reproduced and main- tained a natural population pattern. Third, the sediment porosity and water content was similar to field observations because the drainage pattern of the mesocosms is quite similar to most marsh areas, where lateral porewater movement is significant only adjacent to marsh creeks (Nuttle \& Hemond 1988). The organic matter content, on the other hand, was elevated compared to most salt marshes, due to the large amount of dead root biomass contained by the sediment prior to mesocosm establishment. Moreover, the development of a thick algal mat in Meso I was not anticipated, but is similar to the rich Vaucheria communities reported from the Wadden Sea area (Long \& Mason 1983). In any case, the results obtained in this study should be applicable to field conditions. 


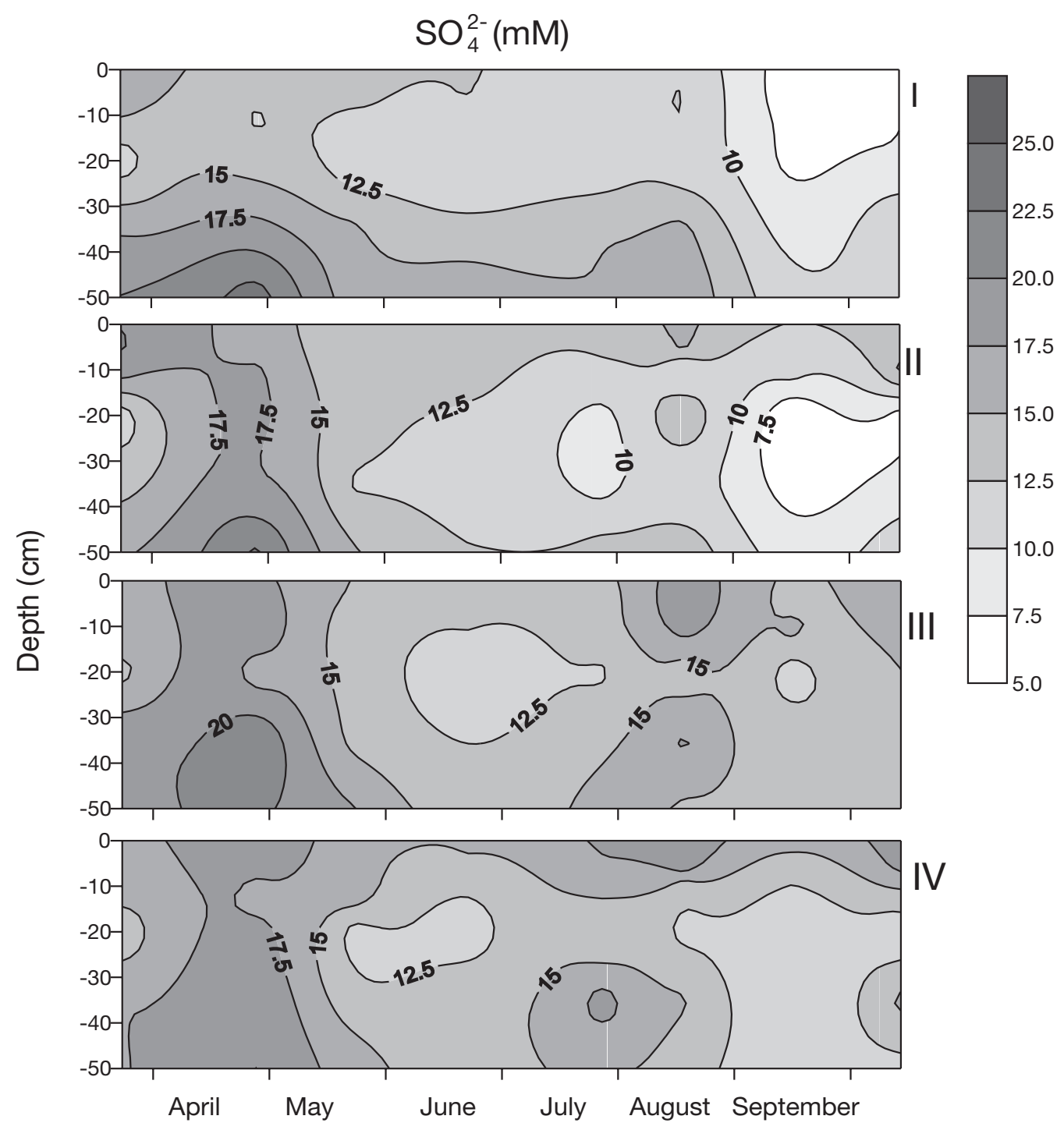

Fig. 7. Porewater $\left[\mathrm{SO}_{4}{ }^{2-}\right]$ in the 4 mesocosms from March to October 2000

\section{Plant-animal interactions}

Dense vegetation of Spartina anglica has pronounced antagonistic effects on Nereis diversicolor, while the impact of worms on plants appears to be minor. The reduced fitness of $N$. diversicolor in the presence of plants (Meso III) may be a result of food limitation, as shading of the substrate by S. anglica must inhibit benthic algal growth considerably. In addition, the presence of dense masses of roots and rhizomes may prevent the fauna from constructing burrow structures and thus strengthen the negative effect of plants (Levin \& Talley 2000). The development of a thick algal mat in the ungrazed Meso I compared to the grazed Meso II demonstrates the need of
$N$. diversicolor to feed on benthic algae and this worm's capacity to maintain the surface continually free of algae. These results are consistent with recent field surveys from a mature Dutch $S$. anglica salt marsh, where macrofauna was abundant on the unvegetated mudflat but scarce within the vegetation (Gribsholt 2001). Additionally, S. anglica and S. foliosa marshes in the UK and western USA show a greater diversity or density as well as a different species composition of macrofauna in unvegetated pools (Frid \& James 1989) and mudflats (Jackson 1985, Frid \& James 1989, Levin et al. 1998) compared with the vegetated marsh. S. alterniflora marshes on the Atlantic coast of North America, on the other hand, generally exhibit high densities of small subsurface-deposit-feeding 


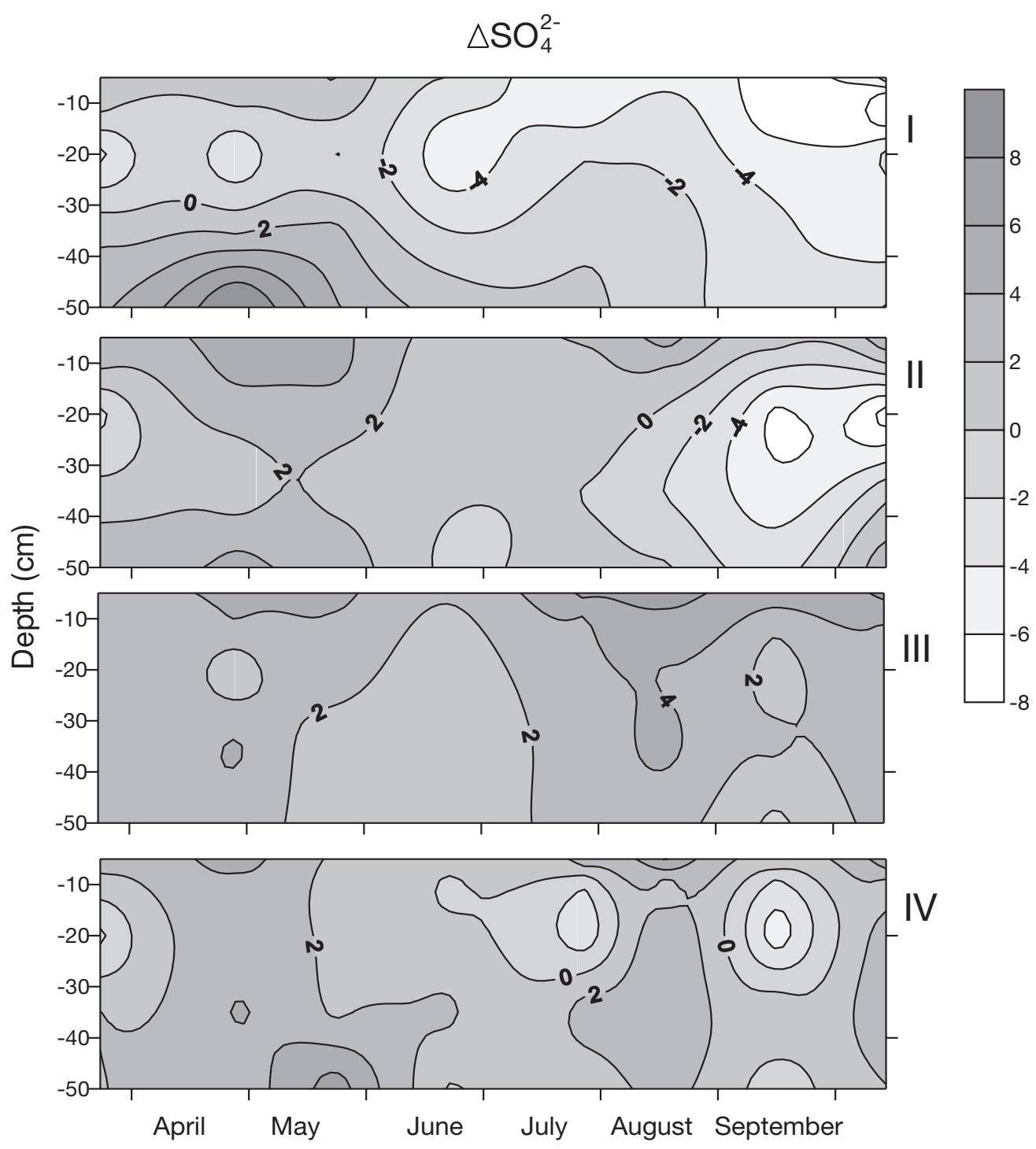

Fig. 8. Changes in porewater $\left[\mathrm{SO}_{4}{ }^{2-}\right]$ normalized for changes in chlorinity $\left(\Delta \mathrm{SO}_{4}{ }^{2-}\right)$ in the 4 mesocosms from March to October 2000

taxa such as Capitella and mobile crustaceans within the vegetation (Levin \& Talley 2000).

Regardless of the presence of Nereis diversicolor, the seedlings planted in our mesocosms became well established in spring. Contrary to this observation, Emmerson (2000) reported that $N$. diversicolor limit the colonization and establishment of Spartina anglica in the pioneer zone of an English marsh. The lower root biomass in the upper sediment layers of Meso III indicated that faunal disturbance affects root growth of $S$. anglica. However, the high root biomass in Meso IV may instead be a response to the more reduced sediment conditions under which Spartina is known to increase the root:shoot biomass ratio (Mitch \& Gosselink 1993, Gribsholt 2001). The oxidizing effects of burrowing and irrigation activities by $N$. diversicolor (Aller 1982) may therefore alleviate the need for excessive root production in Meso III. Thus, when salt marsh creation is used as a strategy in coastal zone management, due to increasing concern over global warming and expected sea level rise (Boorman 1999), size and density of seedlings as well as planting season and location should be considered with care.

\section{Kinetics and stoichiometry of carbon oxidation}

Quantification of carbon mineralization from measurements of SRR by the ${ }^{35} \mathrm{~S}$ technique requires a reliable conversion from sulfur to carbon units. The actual 


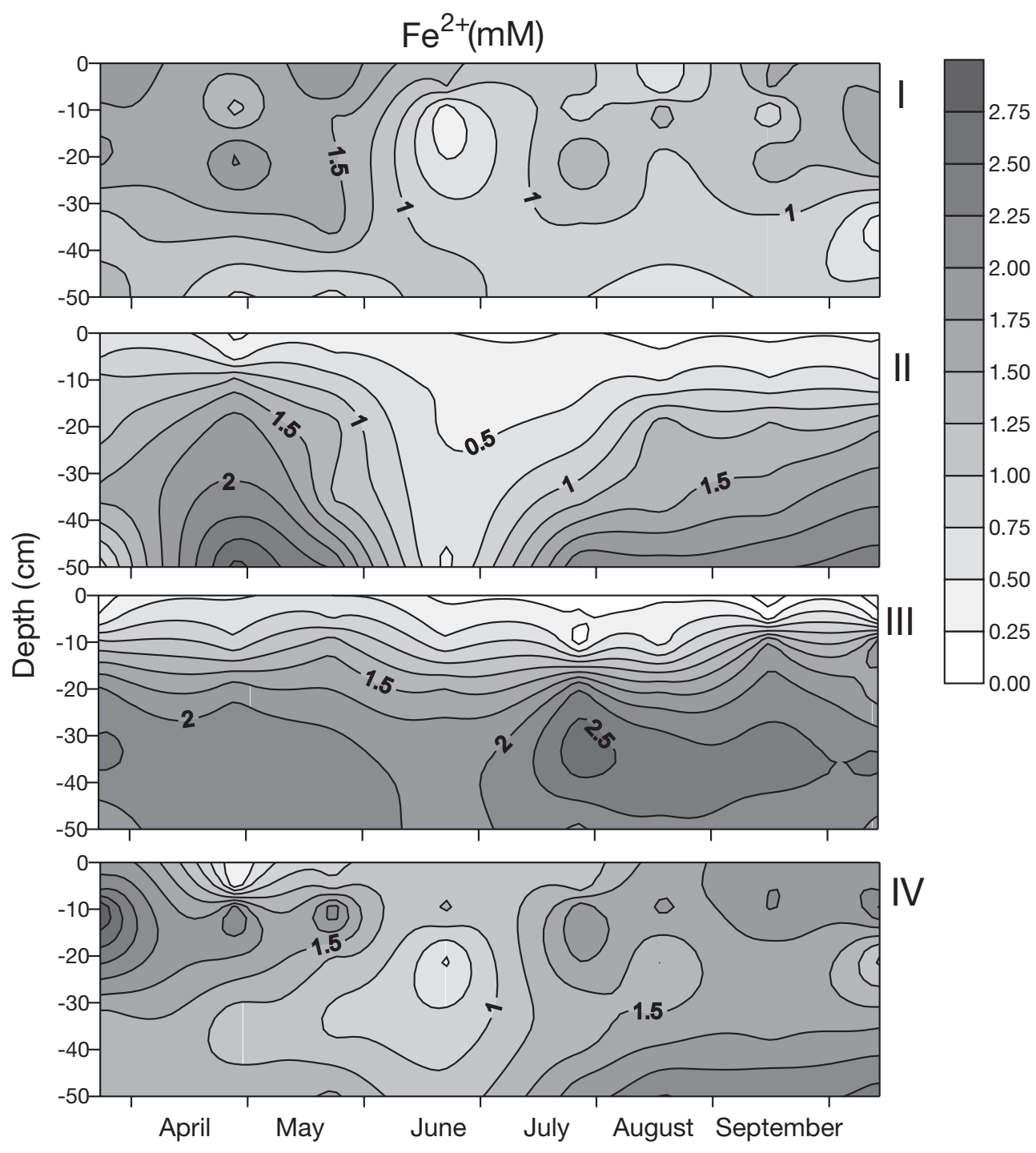

Fig. 9. Porewater $\left[\mathrm{Fe}^{2+}\right]$ in the 4 mesocosms from March to October 2000

conversion factor depends on the oxidation state of the organic carbon being oxidized (Hammond et al. 1996). By assuming that solute transport occurs via molecular diffusion and that a steady state has been approached, the ratio between carbon oxidation and sulfate reduction can be estimated from the slope of porewater $\mathrm{TCO}_{2}$ versus $\mathrm{SO}_{4}{ }^{2-}$ plots (Berner 1980), by correction for different diffusivities of the 2 solutes as described by Kristensen \& Hansen (1999) (Table 4). The C:S ratios of $1.4,1.5,1.0$ and 1.2 obtained by this technique for Mesos I to IV, respectively, are lower than the theoretical C:S stoichiometry of 2.0 when only lactate and acetate $\left(\mathrm{CH}_{2} \mathrm{O}\right)$ are oxidized. While this theoretical ratio is supported by several studies (e.g. Burdige 1991, Boudreau et al. 1992, Kristensen \& Hansen 1995), low $(<2.0) \mathrm{C}$ :S ratios have previously been reported in anoxic sediment incubations of organic rich marine sediments (Alperin et. al 1994, Thomsen \& Kristensen 1997). If our estimated C:S ratios are valid, a high fraction of more reduced organic carbon compounds, such as pyruvate and ethanol, must be utilized by the sulfate reducers in salt marsh sediment.

By considering the relative duration of inundation and air exposure, and by assuming C:S ratios in each mesocosm as estimated above, the contribution of SRR to the depth-integrated $(0$ to $50 \mathrm{~cm}$ ) carbon oxidation can be estimated. The role of sulfate reduction for the carbon oxidation in Mesos II to IV was generally lowest in summer (22 to $50 \%$ ), intermediate in the fall (28 to $59 \%$ ) and highest in spring (34 to 60) (Fig. 10), except for Meso IV where sulfate reduction contributed an increasing proportion over the season. It was surpris- 


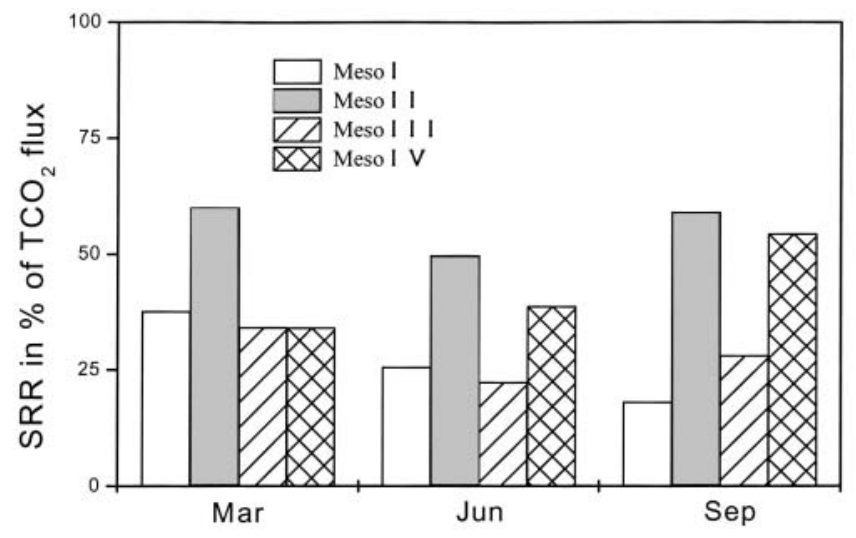

Fig. 10. Depth-integrated sulfate reduction rate ( $\Sigma S R R)$ in the upper $50 \mathrm{~cm}$ of the sediment given as \% of dark carbon dioxide flux $\left(\left[\mathrm{C}: \mathrm{S}\right.\right.$ ratio $\times \Sigma \mathrm{SRR} / \mathrm{CO}_{2}$ flux $\left.] \times 100\right)$ in the 4 mesocosms in March, June and September 2000. The C:S ratio calculated from porewater concentrations in each mesocosm has been applied (see 'Discussion')

ing, however, that the importance of sulfate reduction in Meso I generally was lower than in the other mesocosms. This is probably caused by an excessive and increasing contribution to the measured $\mathrm{CO}_{2}$ flux by aerobic algal respiration within the growing algae mat through time. Otherwise, sulfate reduction was clearly the dominant microbial degradation process at all times of the year in the black and sulfidic (distinct sulfide smell) sediment underlying the mat in Meso I. This was also evident from the depletion of porewater sulfate and the distinct communities of sulfide-oxidizing bacteria observed at the sediment-algal mat interface.

The limited seasonal effect on total mineralization rates in mesocosms as opposed to field observations, where SRR and $\mathrm{CO}_{2}$ flux vary seasonally with highest rates during warm summer months (Howes et al. 1984, Boje 2000), is probably a consequence of the relatively limited range of temperatures under which rate measurements were conducted. However, the gradual increase in porewater DOC and associated buildup of metabolic endproducts $\left(\mathrm{TCO}_{2}\right)$ (linear regression, $\mathrm{p}<$ $0.0001, R=0.61$; Table 4 ) over the spring to fall period in our mesocosms suggests that carbon oxidation is gradually enhanced through time. The concomitant increase in $\mathrm{O}_{2}$ uptake during summer may thus be due to increased reoxidation of reduced iron as indicated by the accumulation of porewater $\mathrm{Fe}^{2+}$.

Air exposure caused a significant increase in oxygen demand by all 3 mesocosms with plant growth (Mesos I, III and IV), while inundation mostly increased $\mathrm{CO}_{2}$ release in unvegetated sediment. Field studies have shown that inundation generally has a minor effect on gas fluxes in unvegetated mudflat sediments, but significantly decreases fluxes in vegetated sediment in both salt marshes (Gribsholt 2001) and mangrove forests (Kristensen et al. 1994, Holmer et al. 1999). The increased $\mathrm{O}_{2}$ flux in air-exposed and vegetated sediment is attributed to an increase in the area of oxicanoxic interfaces due to topography and drainage (Kristensen et al. 1992). However, the discrepancy of flux behavior in unvegetated sediment between our mesocosms and data obtained from field studies (Gribsholt 2001) are probably caused by differences in basic sediment characteristics. The organic-poor open mudflat sediments examined in field studies are in reality not comparable to the previously vegetated and organic-rich sediment used as a mudflat analog in our mesocosm study. Higher rates of sulfate reduction fuelled by the gradual decay of the large mass of dead roots and rhizomes present (Howarth \& Hobbie 1982) probably results in a higher sediment oxygen demand for sulfide oxidation compared to organic poor mudflat sediments. In any case, the generally higher RQ values observed in inundated than in air-exposed mesocosm sediments is in agreement with field observations and suggest a buildup of reduced metabolites during water cover and a higher degree of reoxidation during air exposure.

\section{Effect of bioturbation on sediment biogeochemistry}

Infaunal animals displace sediment particles and increase the exchange of sediment porewater with

Table 4. Coefficients of linear relationships $(y=a+b x)$ of porewater species from all sampling occasions. The relationship between $\mathrm{TCO}_{2}$ and $\mathrm{SO}_{4}{ }^{2-}$ is presented for each mesocosm. In the relationships between $\mathrm{TCO}_{2}$ and $\Delta \mathrm{SO}_{4}{ }^{2-}$ as well as DOC, the data from all 4 mesocosms are pooled

\begin{tabular}{|c|c|c|c|c|c|c|}
\hline Mesocosm & $y$ & $x$ & $a$ & $b$ & $\mathrm{R}$ & $\mathrm{p}$ \\
\hline I & $\mathrm{TCO}_{2}$ & $\mathrm{SO}_{4}{ }^{2-}$ & 40.34 & -1.31 & -0.72 & $<0.0001$ \\
\hline II & $\mathrm{TCO}_{2}$ & $\mathrm{SO}_{4}{ }^{2-}$ & 39.20 & -1.37 & -0.43 & $<0.0001$ \\
\hline III & $\mathrm{TCO}_{2}$ & $\mathrm{SO}_{4}{ }^{2-}$ & 32.15 & -0.92 & -0.44 & $<0.0001$ \\
\hline IV & $\mathrm{TCO}_{2}$ & $\mathrm{SO}_{4}{ }^{2-}$ & 35.20 & -1.05 & -0.45 & $<0.0001$ \\
\hline I to IV & $\mathrm{TCO}_{2}$ & $\Delta \mathrm{SO}_{4}{ }^{2-}$ & 7.10 & -0.29 & -0.61 & $<0.0001$ \\
\hline I to IV & $\mathrm{TCO}_{2}$ & DOC & 11.14 & 3.06 & 0.61 & $<0.0001$ \\
\hline
\end{tabular}


overlying water through their burrowing, feeding and ventilation activities (Kristensen 1985). $\mathrm{O}_{2}$ uptake by sediments is the result of aerobic and anaerobic metabolism of benthic organisms and of the interaction between oxygen diffusing into the sediment and reduced compounds diffusing out. Thus, by increasing the area of sediment-water interfaces and through their ventilation activity, the presence of burrowing animals enhances solute transport in sediments (Aller 1982).

In our mesocosm study, no clear effect of Nereis diversicolor on sediment fluxes could be revealed. A similar lack of any long-term flux response in the presence of $N$. diversicolor has been observed in other organic-rich sediments (Hansen \& Kristensen 1997). However, the effect of bioturbation on solute transport is clearly evident as low porewater concentrations of $\mathrm{TCO}_{2}$, DOC and $\mathrm{Fe}^{2+}$ in the top 15 to $20 \mathrm{~cm}$ of the sediment in Meso II. Bioturbation impact of the fewer (but large) individuals of $N$. diversicolor in Meso III is clealy lower than in Meso II, but still noticeable.

\section{Effect of plants on sediment biogeochemistry}

Oxygen is depleted within the top few mm of most marine sediments, below which reducing conditions prevail (Revsbech et al. 1980). Salt marsh sediments, however, are greatly affected by the presence of vegetation. Through downward translocation of oxygen and associated root leakage, marsh grasses create a heterogeneous environment with a mosaic of oxic and oxidized subsurface microniches (rhizospheres) (Holmer et al. 2002). The low C:S ratios estimated above for vegetated compared to unvegetated sediment may therefore partly reflect a high degree of reoxidation of sulfide by root oxygen leakage. Further evidence of the capacity of $S$. anglica to maintain an oxidized rhizosphere was observed by the formation of ferric iron plaques visible on the root surfaces as described by Sundby et al. (1998).

Live and healthy roots of Spartina anglica were found throughout the depth of Mesos III and IV, and their effect on sediment biogeochemistry was apparent throughout the entire $50 \mathrm{~cm}$ sediment column. Furthermore, root leakage of DOC and fermentation products from anaerobic root metabolism enhances microbial activity in the rhizosphere (Hines et al. 1989). Although there is no clear impact of plants on measured sulfate reduction rates, the total mineralization was considerably higher in vegetated (Mesos I, III and IV) than unvegetated sediments (Meso II). This is in agreement with field observations from similar sediments in Dutch salt marshes (Gribsholt 2001) and from mangrove sediment (Holmer et al. 1999). Furthermore, the low con- tribution of sulfate reduction to the total carbon oxidation $(<54 \%)$ in vegetated mesocosms corresponds well with field observations, where sulfate reduction in a S. anglica marsh, repeatedly (September 1998 to 2000) contributed only 20 to $33 \%$ of the total C oxidation (B. Gribsholt unpubl. data). Thus, the enhanced carbon oxidation in the vegetated sediment is probably mediated by increased aerobic and iron respiration as found in other salt marsh and mangrove environments (Kristensen et al. 2000, Kostka et al. 2002). Ferric iron is supplied by oxidation of ferrous iron within the oxidizing rhizosphere environment.

Effects of roots on mineralization pathways in the mesocosms are also evident from porewater profiles. The most pronounced effect is the constantly low [DOC] in Mesos III and IV compared to Mesos I and II. Most of the indigenous DOC pool is composed of complex macromolecules, which are inaccessible to many anaerobic respiring bacteria. However, the degradation of relatively refractory DOC may be coupled to the overall metabolic activity of sediments (Canfield 1994), in the sense that stimulation of fermentative and respiring bacteria by the labile DOC leaching from living roots and rhizomes in the more reduced parts of the sediment (Howarth \& Hobbie 1982) results in cometabolism and thus, enhanced oxidation of the more refractory DOC. Many aerobic microorganisms, on the other hand, have the enzymatic capacity to perform a total and rapid mineralization of complex organic substrates (Kristensen \& Holmer 2001). Such complete mineralization of otherwise refractory DOC by aerobic processes driven by oxygen leakage from plant roots and rhizomes may be yet another mechanism by which DOC mineralization is enhanced in the vegetated salt marsh mesocosms. Furthermore, diurnal redox oscillations in the rhizosphere coupled to plant photosynthetic activity (Holmer et al. 2002), may promote decomposition of partly degraded sediment detritus (Hulthe et al. 1998). We suggest, therefore, that the DOC pool in the vegetated mesocosm is kept low by a combination of relatively fast aerobic oxidation within the rhizosphere and stimulated anaerobic oxidation of refractory DOC in the surrounding reduced sediment, due to cometabolism with labile DOC leached from roots.

\section{CONCLUSION}

Salt marsh sediment vegetated by Spartina anglica is an unsuitable habitat for Nereis diversicolor due to limited food availability. When unaffected by plants or animals, salt marsh sediment is greatly reduced and sulfate reduction is the dominant degradation pathway (Fig. 11). Irrigation by N. diversicolor flushes the top 15 


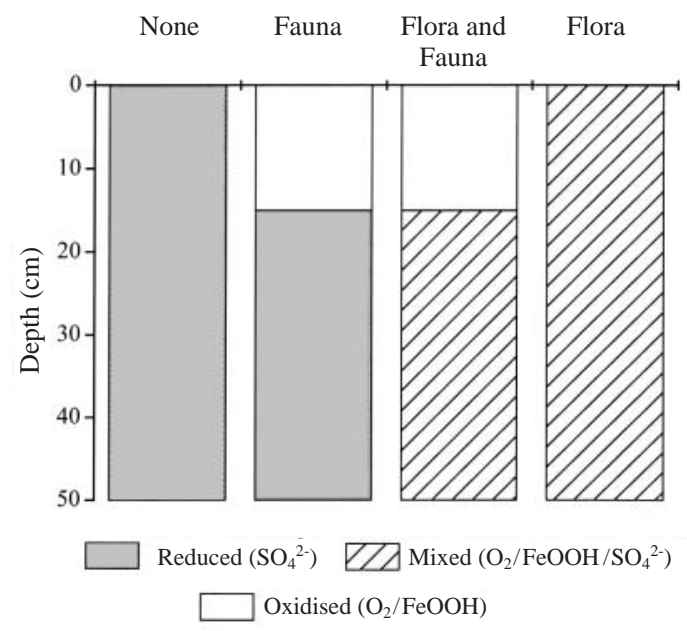

Fig. 11. Partitioning of electron acceptors in the top $50 \mathrm{~cm}$ of the sediment in the mesocosms when unaffected by macroorganisms or affected by fauna, flora or both

to $20 \mathrm{~cm}$ sediment resulting in a dominance of oxic and suboxic reduction pathways. Anoxic microniches in the bioturbated zone may support some sulfate reduction, which otherwise dominates below the depth of bioturbation. The presence of flora (S. anglica) creates a mosaic of reduced, oxic and oxidized microniches with high total mineralization rates throughout the top $50 \mathrm{~cm}$ depth, due to co-occurrence of carbon-oxidizing bacteria using $\mathrm{O}_{2}, \mathrm{FeOOH}$ and $\mathrm{SO}_{4}{ }^{2-}$ as terminal electron acceptors. The greatest enhancement of total carbon oxidation in salt marsh sediment occurs when both flora and fauna are present.

Acknowledgements. We thank Susanne Matzen and Hanne Brandt for technical assistance and Leslie Lambregts for providing the aboveground plant data. This research was supported by the EU research program 'Preserving the Ecosystem' under the ISLED project Contract ENV4-CT97-0582 (ELOISE contribution no. 266/17).

\section{LITERATURE CITED}

Adam P (1990) Saltmarsh ecology. Cambridge University Press, Cambridge

Aller RC (1982) The effects of macrobenthos on chemical properties of marine sediment and overlying water. In: McCall PL, Tevesz MJS (eds) Animal-sediment relations. Plenum Publishing, New York, p 53-102

Aller RC (2001) Transport and reactions in the bioirrigated zone. In: Boudreau BP, Jørgensen BB (eds) The benthic boundary layer: transport processes and biogeochemistry. Oxford University Press, Oxford, p 269-301

Alongi DM (1998) Coastal ecosystem processes. CRC Press, New York, p 43-92

Alperin MJ, Albert DB, Martens CS (1994) Seasonal variation in production and consumption rates of organic carbon in an organic-rich coastal sediment. Geochim Cosmochim Acta 58:4909-4930
Berner RA (1980) Early diagenesis: a theoretical approach Princeton University Press, Princeton

Bertness MD (1985) Fiddler crab regulation of Spartina alterniflora production on a New England salt marsh. Ecology 66:1042-1055

Boje J (2000) The effect of Spartina anglica on sulfate reduction and sulfur cycling in the Wadden Sea. MSc thesis, Odense University-SDU (in Danish)

Boorman LA (1999) Salt marshes-present functioning and future change. Mangroves Salt Marshes 3:227-241

Boudreau BP, Canfield DE, Mucci A (1992) Early diagenesis in a marine sapropel, Mangrove Lake, Bermuda. Limnol Oceanogr 37:1738-1753

Burdige DJ (1991) The kinetics of organic matter mineralization in anoxic marine sediments. J Mar Res 49:727-761

Canfield DE (1994) Factors influencing organic carbon preservation in marine sediments. Chem Geol 114:315-329

Cline JD (1969) Spectrophotometric determinations of hydrogen sulfide in natural waters. Limnol Oceanogr 14: 454-458

Emmerson M (2000) Remedial habitat creation: does Nereis diversicolor play a confounding role in the colonisation and establishment of the pioneering saltmarsh plant, Spartina anglica? Helgol Mar Res 54:110-116

Fossing H, Jørgensen BB (1989) Measurement of bacterial sulfate reduction in sediments: evaluation of a single-step chromium reduction method. Biogeochemistry 8:205-222

Frid C, James R (1989) The marine invertebrate fauna of a British coastal salt marsh. Holarct Ecol 12:9-15

Gribsholt B (2001) The influence of macrophytes and benthic infauna on rates and pathways of carbon mineralization in salt marsh sediments. $\mathrm{PhD}$ thesis, Odense University-SDU

Gribsholt B, Kristensen E (2002) Impact of sampling methods on sulfate reduction rates and dissolved organic carbon (DOC) concentrations in vegetated salt marsh sediments. Wetlands Ecol Manage (in press)

Hall P, Aller RC (1992) Rapid, small-volume, flow injection analysis for $\Sigma \mathrm{CO}_{2}$ and $\mathrm{NH}_{4}{ }^{+}$in marine and freshwaters. Limnol Oceanogr 37:1113-1119

Hammond DE, McManus J, Berelson WM, Kilgore TE, Pope RH (1996) Early diagenesis of organic material in equatorial Pacific sediments: stoichiometry and kinetics. DeepSea Res 43:1365-1412

Hansen K, Kristensen E (1997) Impact of macrofaunal recolonisation on benthic metabolism and nutrient fluxes in a shallow marine sediment previously overgrown with macroalgal mats. Estuar Coast Shelf Sci 45:613-628

Hines ME, Knollmeye SL, Tugel JB (1989) Sulfate reduction and other sedimentary biogeochemistry in a northern New England salt marsh. Limnol Oceanogr 34:578-590

Hines ME, Evans RS, Genthner BRS, Willis SG, Friedman S, Rooney-Varga JN, Devereux R (1999) Molecular phylogenetic and biogeochemical studies of sulfate-reducing bacteria in the rhizosphere of Spartina alterniflora. Appl Environ Microbiol 65:2209-2216

Holmer M, Andersen FØ, Holmboe N, Kristensen E, Thongtham N (1999) Transformation and exchange processes in the Bangrong mangrove forest-seagrass bed system, Thailand: seasonal and spatial variations in benthic metabolism and sulfur biogeochemistry. Aquat Microb Ecol 20:203-212

Holmer M, Gribsholt B, Kristensen K (2002) Effects of sea level rise on growth of Spatrina anglica and oxygen dynamics in rhizosphere and salt marsh sediments. Mar Ecol Prog Ser 225:197-204

Howarth RW, Hobbie JE (1982) The regulation of decomposition and heterotrophic activity in salt marsh soils: a review. 
In: Kennedy VS (ed) Estuarine comparisons. Academic Press, New York, p 183-207

Howes BL, Dacey JWH, King GM (1984) Carbon flow through oxygen and sulfate reduction pathways in salt marsh sediments. Limnol Oceanogr 29:1037-1051

Hulthe G, Hulth S, Hall PO (1998) Effect of oxygen on degradation rate of refractory and labile organic matter in continental margin sediment. Geochim Cosmochim Acta 62: $1319-1328$

Jackson D (1985) Invertebrate populations associated with Spartina anglica salt-marsh and adjacent intertidal mud flats. Estuar Brackishwater Sci 40:8-14

Jørgensen BB (1977) The sulfur cycle of a coastal marine sediment (Limfjorden, Denmark). Limnol Oceanogr 22: $814-832$

Jørgensen BB (1978) A comparison of methods for quantification of bacterial sulfate reduction in coastal marine sediments. Geomicrobiol J 1:11-27

Kostka JE, Gribsholt B, Petrie E, Dalton D, Skelton H, Kristensen $E$ (2002) The rates and pathways of carbon oxidation in bioturbated saltmarsh sediments. Limnol Oceanogr 47:230-240

Kristensen E (1985) Oxygen and inorganic nitrogen exchange in a Nereis virens (Polychaeta) bioturbated sedimentwater system. J Coast Res 1:109-116

Kristensen E (1993) Seasonal variations in benthic community metabolism and nitrogen dynamics in a shallow, orgaincpoor Danish lagoon. Estuar Coast Shelf Sci 36:565-586

Kristensen E, Andersen FØ (1987) Determination of organic carbon in marine sediments: a comparison of two CHNanalyzer methods. J Exp Mar Biol Ecol 109:15-23

Kristensen E, Hansen K (1995) Decay of plant detritus in organic-poor marine sediment: production rates and stoichiometry of dissolved C and N compounds. J Mar Res 53: 675-702

Kristensen E, Hansen K (1999) Transport of carbon and ammonium in bioturbated (Nereis diversicolor) coastal, marine sediments. Biogeochemistry 45:147-168

Kristensen E, Holmer M (2001) Decomposition of plant materials in marine sediment exposed to different electron acceptors $\left(\mathrm{O}_{2}, \mathrm{NO}_{3}{ }^{-}\right.$, and $\left.\mathrm{SO}_{4}{ }^{2-}\right)$, with emphasis on substrate origin, degradation kinetics, and the role of bioturbation. Geochim Cosmochim Acta 65:419-433

Kristensen E, Devol AH, Ahmed SI, Saleem M (1992) Preliminary study of benthic metabolism and sulfate reduction in a mangrove swamp of the Indus Delta, Pakistan. Mar Ecol Prog Ser 90:287-297

Editorial responsibility: Otto Kinne (Editor), Oldendorf/Luhe, Germany
Kristensen E, King GM, Holmer M, Banta GT, Jensen MH, Hansen K, Bussarawit N (1994) Sulfate reduction, acetate turnover and carbon metabolism in sediments of the Ao Nam Bor mangrove, Phuket, Thailand. Mar Ecol Prog Ser 109:245-255

Kristensen E, Andersen FØ, Holmboe N, Holmer $M$, Thongtham N (2000) Carbon and nitrogen mineralisation in the sediments of the Bangrong mangrove area, Phuket Thailand. Aquat Microb Ecol 22:199-213

Levin LA, Talley TS (2000) Influence of vegetation and abiotic environmental factors on salt marsh invertebrates. In: Weinstein MP, Kreeger DA (eds) Concepts and controversies in tidal marsh ecology. Kluwer Academic Publishers, Dordrecht, p 661-707

Levin LA, Talley TS, Hewitt J (1998) Macrobenthos of Spartina foliosa (Pacific cordgrasss) salt marshes in southern California: community structure and comparison to a Pacific mudflat and a Spartina alteriflora (Atlantic smooth cordgrass) marsh. Estuaries 21:129-144

Long SP, Mason CF (1983) Saltmarsh ecology. Blackie \& Son, Glasgow

Mason CF, Heath DJ, Gibbs DJ (1991) Invertebrate assemblages of Essex salt marshes and their conservation importance. Aquat Conserv 1:123-137

Mitsch JM, Gosselink JG (1993) Wetlands. Van Nostrand Reinhold, New York

Montague CL (1982) The influence of fiddler crab burrows and burrowing on metabolic processes in salt marsh sediment. In: Kennedy VS (ed) Estuarine comparisons. Academic Press, New York, p 283-301

Nuttle WK Hemond HF (1988) Salt marsh hydrology: implications for biogeochemical fluxes to the atmosphere and estuaries. Global Biogeochem Cycles 2:91-114

Parson TR, Maita Y, Lalli CM (1984) A manual of chemical and biological methods for seawater analysis. Pergamon, Oxford

Revsbech N, Sørensen J, Blackburn TH, Lomholt JP (1980) Distribution of oxygen in marine sediments measured with microelectrodes. Limnol Oceanogr 24:403-411

Stookey LL (1970) Ferrozine-a new spectrophotometric reagent for iron. Anal Chem 42:779-781

Sundby B, Vale C, Cacador I, Catarino FM, Madureira MJ, Caetarino F (1998) Metal-rich concentrations on the roots of salt marsh plants: mechanism and rate of formation. Limnol Oceanogr 43:245-252

Thomsen U, Kristensen E (1997) Dynamics of $\Sigma \mathrm{CO}_{2}$ in a surficial sandy marine sediment: the role of chemoautotrophy. Aquat Microb Ecol 12:165-176

Submitted: July 6, 2001; Accepted: May 24, 2002

Proofs received from author(s): September 3, 2002 